\title{
Lansky Performance Status 0
}

National Cancer Institute

\section{Source}

National Cancer Institute. Lansky Performance Status O. NCI Thesaurus. Code C70538.

Unresponsive. 